\title{
PEMBERDAYAN IBU-IBU KELOMPOK PROGRAM KELUARGA HARAPAN (PKH) MELALUI PENINGKATAN PRODUKTIF DI KELURAHAN DELI TUA BARAT
}

\author{
Novita Indah Hasibuan ${ }^{1 *}$, Khairunnisa Harahap ${ }^{2}$, Uli Basa Sidabutar ${ }^{3}$ \\ ${ }^{1}$ Jurusan Pendidikan Ekonomi, Fakultas Ekonomi, Universitas Negeri Medan, Medan, Indonesia \\ ${ }^{2} J u r u s a n$ Akuntansi, Fakultas Ekonomi, Universitas Negeri Medan, Medan, Indonesia \\ ${ }^{3}$ Jurusan Elektro, Fakultas Teknik, Universitas Negeri Medan, Medan, Indonesia \\ * Penulis Korespodensi : novitaindah528@gmail.com
}

\begin{abstract}
Abstrak
Kelurahan Deli Tua Barat yang terletak di Kecamatan Deli Tua mempunyai kelompok Program Keluarga Harapan (PKH) yang perlu diperhatikan untuk kesinambungan kehidapan mereka, serta untuk memperbaiki taraf hidup mereka. Tujuan dari kegiatan Program Pengabdian kepada Masyarakat ini untuk melaksanakan tri dharma perguruan tinggi dan juga untuk membantu mitra mencari solusi dalam menghadapi segala permasalahan yang dihadapi mitra dalam mengembangkan usahanya khususnya dalam hal pengelolaan dan manajemen usaha, pembuatan kuliner yang terbuat dari hasil kuliner di Kecamatan Deli tua seperti : pengolahan tapai menjadi aneka cake, bolu dan donat Metode yang dipakai dalam kegiatan Program BOPTN ini adalah pendidikan, pelatihan produksi, manajemen usaha, penyuluhan, serta dilakukan program pendampingan.Hasil kegiatan yang sudah dicapai, yaitu: 1) Adanya produk baru berupa cake, bolu dan donat berbahan dasar tape. 2) Adanya alat bantu produksi berupa mixer, oven, dan ampia. 3) Kelompok PKH memiliki desain kemasan produk baru.Diharapkan dengan adanya Program Pengabdian kepada Masyarakat ini akan terbentuk usaha masyarakat yang mandiri secara ekonomi dan tentunya akanmemberikan kontribusi yang positif terhadap masyarakat dan lingkungannya.
\end{abstract}

Kata Kunci : Produktif, Pendampingan, Aneka Cake

\begin{abstract}
Kelurahan Deli Tua Barat located in Kecamatan Deli Tua has a Program Keluarga Harapan (PKH) group that needs to be considered for their continuous existence, and to improve their standard of living. The purpose of this Community Service Program activity is to carry out tri dharma college and also to help partners find solutions in facing all problems faced by partners in developing their business especially in management and business management, culinary manufacture made from culinary in Kecamatan Deli old such as: processing tapai into various cakes, sponges and donuts Method used in the activities of this BOPTN Program is education, production training, business management, counseling, and accompaniment program. The results of activities that have been achieved, namely: 1) The existence of new products in the form of cake, spoon and donut based tape. 2) The existence of production aids in the form of mixer, oven, and ampia. 3) PKH Group has new product packaging design. It is hoped that this Community Service Program will form an independent community business economically and will certainly contribute positively to the society and its environment.
\end{abstract}

Keywords: Productive, Assistance, Assorted Cakes

\section{PENDAHULUAN}

Program Keluarga Harapan (PKH) juga merupakan program pemberian uang tunai kepada Rumah Tangga Sangat Miskin (RTSM) berdasarkan persyaratan dan ketentuan yang telah ditetapkan dengan melaksanakan kewajibannya. Program semacam ini secara internasional dikenal sebagai program conditional cash transfers (CCT) atau program Bantuan Tunai Bersyarat. Persyaratan tersebut dapat berupa kehadiran di fasilitas pendidikan (misalnya bagi anak usia sekolah), ataupun kehadiran di fasilitas kesehatan (misalnya bagi anak balita, atau bagi ibu hamil). Kelurahan Deli Tua Barat yang berada di Kecamatan Deli Tua ada sekitar 89 kepala keluarga yamg mendapatkan bantuan Program Keluarga Harapan (PKH) dari Pemerintah. Dari 89 kepala keluarga yang mendapat Program Keluarga Harapan (PKH) mereka membentuk menjadi tiga kelompok yaitu Andaliman yang diketuai oleh ibu Sri wati yang jumlah anggotanya sekitar 20 kepala 
keluarga, yang kedua kelompok Kenanga yang diketuai Juliana yang jumlah anggotanya sekitar 25 kepala keluarga, dan yang ke tiga kelompok kenaga yang diketua oleh ibu Juliana yang jumlah anggotanya 30 anggota. Rata-rata mata pencaharian mereka yang mendapatkan PKH rata - rata menjadi pembantu rumah tangga (PRT). Selama ini Kelurahan Deli Tua Barat, Kecamatan Deli Tua, Kabupaten Seli Serdang tepatnya di Jalan Pamah LK.III. GG. Tumiran No.03, selama ini pihak kelurahan telah mencoba menfasilitas kelompok Program Keluarga Harapan (PKH)dengan program pemberdayaan ekonomi masyarakat pedesaan khususnya ibu rumah tangga untuk mengasa kreatifitas dibidang kuliner maupun kerajinan, Program ni dikhususkan untuk ibu rumah tangga yang berada di Kelurahan Deli Tua Barat, agar mereka mempunyai kemampuan dalam mengola dan menciptakan prodak kuliner dan kerajinan. Ada beberapa ibu rumah tangga yang menjadi anggota PKH Andaliman dan Kenanga tersebut sudah mulai membuat usaha kecil-kecilan untuk menambah income rumah tangga mereka seperti membuat kue/penganan kecil (kering dan basah). PKH Andaliman dan Kenanga berdiri sejak tahun 2015 telah berjalan selamah kurang lebih empat tahun dan relatif belum mampu berjalan secara independen tanpa instruktur dan pendampingan dari pihak Kecamatan. Secara teknik pendamping yang juga merupakan staf dari kecamatan (Ibu Nurul) melakukan aktivitas pendampingan pembuatan kuliner dan kerajinan sederhana untuk menghilangkan rasa bosan dan jenuh yang diadakan pada minggu ke-2 setiap bulannya.

Dari ketiga kelompok Program Keluarga Harapan (PKH) yang ada di Kelurahan Deli Tua Barat mereka selalu melakukan pertemuan 2 kali dalam sebulan, yang di pimpin tim pendampingan dari setiap kelurahan, kegiatan rutin ini mereka lakukan untuk membahas tentang :

1. Pemuktahiran data - data kelompok Program Keluarga Harapan (PKH).

2. Menyampaikan informasi kepada anggota program keluarga harapan (PKH) tentang bagaimana meningkatkan produktif.

3. Melaksanakn FDS (Farenting Education)

Diharapakan dari kegiatan yang dilakukan secara rutin ini mempunyai dampak yang positif bagi kelompok kelompok program keluarga harapan (PKH). Melalui program keluarga harapan yang mereka dapatkan biasanya setiap kepala rumah tangga harus mempunyai syarat yang mereka harus lengkapi untuk mendapatkan bantuan dari pemerintah. Melalui kelompok, PKHsetiap keluarga miskin dapat saling berbagi pengalaman, saling berkomunikasi, saling mengenal, dapat menyelesaikan berbagai masalah dan kebutuhan yang dirasakan. Dengan sistem ini, kegiatan usaha yang tadinya dilakukan secara sendirisendiri kemudian dikembangkan dalam kelompok, sehingga setiap anggota dapat meningkatkan pengetahuan dan keterampilan dalam kegiatan usaha ekonomi produktif, usaha kesejahteraan sosial serta kemampuan berorganisasi.Hal inilah yang membuat tim pengusul merasa perlu untuk membantu masyaarakat di Kelurahan Delitua barat khususya para ibu - ibu yang tidak mempunyai pendapatan yang tidak tetap, untuk bisa membuat produk olahan kuliner yang berbahan dasar dari tapai. Kenapa harus tapai, diakarenakan kecamatan Deli Tua termasuk salah satu daerah yang banyak memproduksi tapai.

Hasil survey pertama (10 Mei 2017) di Kelurahan Deli Tua Barat tersebut diketahui terdapat 3 kelompok proram keluarga harapan yang masing-masing mempunyai kegiatan usaha, ada yang bergerak di pengolahan keripik, pembuatan sunlight, minyak wangi dan mengumpulkan plasti-pastik dari sampah. Kelompok yang memiliki usaha kuliner dan kerajinan akan diberikan pendampingan untuk meningkatkan produkting rumah tangga dengan membuat aneka olahan bolu dan donat dari tapai.

Dari hasil survey (10 Mei 2017) tersebut di kelurahan Deli Tua Barat kecamatan Deli Tua diidentifikasi masalah yang dihadapi calon mitra dalam pengentasan kemiskinan adalah peningkatan produktif meliputi inovasi dan pengembangan dalam pengolahan kuliner sebagai income dalam rumah tangga. Pemanfaatan tapai untuk dijadikan beragam produk kuliner edukatif yang bernilai ekonomi tinggi dan pasarnyapun sangat luas sehingga mereka dapat meningkatkan income rumah tangga mereka dan mekapasitas produksinya sekaligus dapat memasarkannya kepada masyarakat.

Hasil pengamatan langsung (10 Mei 2017), diketahui bahwaMitra sudah menekuni usahanya sejak tahun 2015, dari tahun ke tahun bahkan sampai sekarang terus belum mengalami perkembangan. Dalam aspek produksi mitra tidak merasakan manfaatnya bagi pendapatan rumah tangga mereka. Namun demikian dalam perkembangannya usaha yang dilakukan mitra selalu mengalami pasang surut. Dari hasil pengamatan langsung yang dilakukan oleh tim pengusul dapat diidentifikasi beberapa permasalahan yang dihadapi mitra dan perlu untuk dicari solusinya.

Masalah-masalah tersebut teridentifikasi sebagai berikut:

1. Produk kuliner banyak yang sama .

2. Differensiasi Produk dengan memanfaatkan bahan tapai.

3. Pengetahuan dan ketrampilan dalam mengelola bolu dan donat yang berbahan dasar tapai masih rendah.

4. Kebutuhan Alat pembuatan Bolu dan Donat.

\section{HASIL DAN PEMBAHASAN}

Kegiatan program pengabdian masyarakat ini dilaksanakan selama tiga bulan sejak Juli sampai dengan September 2017. Kegiatan tahap awal dimulai dengan melakukan koordinasi dengan jajaran pengurus PKH, Pemerintah Kelurahan Deli Tua Barat dan Pemerintah Kecamatan Deli Tua, Tahap koordinasi dilakukan dengan cara observasi dan 
wawancara langsung ke lokasi dan kantor Kelurahan Deli Tua Barat.

Pelaksanaan program pengabdian tahap kedua diawali dengan melaksanakan Kegiatan pelatihan pembuatan pengolahan tapai menjadi aneka cake dan bolu. Kegiatan dilakukan tanggal 09 Agustus 2017 bertempat di kantor Kelurahan Deli Tua Barat. Para peserta dengan antusias dan sungguh-sungguh mengikuti praktek membuat produkaneka cake, bolu dan donat. Semua peserta hadir tepat waktu dan mengikuti jadwal kegiatan secara tertib. Respon positif para peserta dapat dilihat selain dari kehadiran dan keseriusan ketika acara berlangsung.

Kegiatan berikutnya adalah pelatihan pembuatan donat. Kegiatan dilakukan tanggal 10 Agustus 2017 bertempat di kantor Kelurahan Deli Tua Barat. Tanggapan peserta sangat positif dalam sesi pelatihan yang langsung dilaksanakan di Kantor Kelurahan Deli Tua Barat.Berikut dokumentasi kegiatan yang dilakukan di Kelurahan Deli Tua Barat.
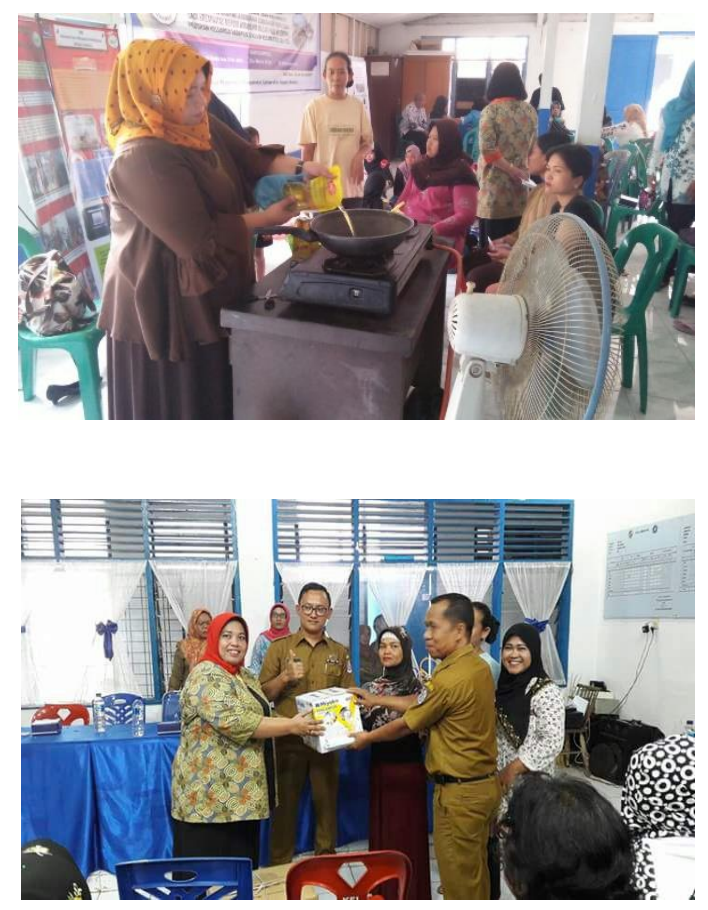

Kegiatan pengabdian ini membina kelompok PKH Kelurahan Deli Tua Barat Kecamatan Deli Tua dalam pembuatan produkaneka cake, bolu dan donatsampai pengemasan produk dan siap dipasarkan. Selain praktek pembuatan produk, dilakukan juga pelatihan peningkatan kemampuan manajerial dan beberapa alat produksi yang meliputi :

a. Peningkatan kemampuan memasarkan produk dengan memberikan materi tentang desain kemasan.

b. Kemampuan manajemen keuangan usaha, permodalan dan pembukuannya.

c. Mixer, Oven dan Ampia

Keseluruhan aktivitas dilakukan dengan metode pendampingan oleh Tim Pelaksana. Pendampingan dilakukan dengan melaksanakan kunjungan ke lokasi usaha, melakukan pertemuan dan praktek pembuatan produk dengan semua kelompok PKH di Kelurahan Deli Tua Barat. Pada kesempatan itu juga dilakukan konsultasi dan pembinaan serta pengarahan atas masalah yang terjadi pada mitra baik PKH di Kelurahan Deli Tua Barat.

Berdasarkan atas pelaksanaan kegiatan pengabdian kepada masyarakat yang sudah dilakukan, maka partisipasi mitra sangat baik dan juga menjadi faktor yang menentukan keberhasilan program pengabdian. Pelaksanaan kegiatan ini dapat meningkatkan minat mitra untuk selalu aktif mengikuti pelatihan-pelatihan. Setelah melakukan penyuluhan, pendampingan dan kunjungan maka jenis luaran yang dihasilkan adalah sebagai berikut:

Luaran yang dihasilkan pada pelaksanaan kegiatan pengabdian kepada masyarakat ini, yaitu: 1) Aneka cake, bolu dan donat, 2) Mixer, Oven dan Ampia, 3) Desain Kemasan Produk, dan 4) Keterampilan dalam manajemen usaha.
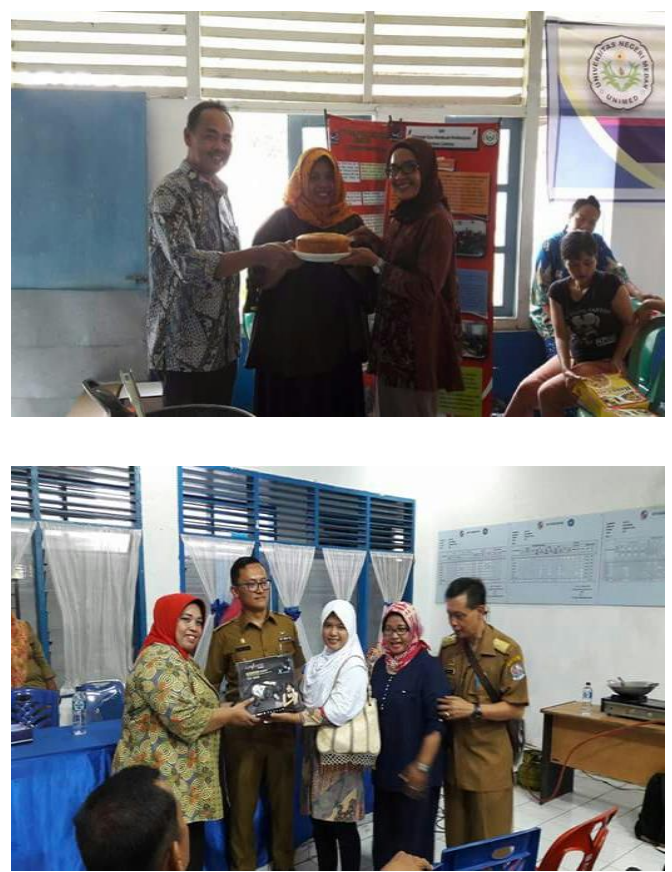

\section{KESIMPULAN}

Berdasarkan pada kegiatan pengabdian kepada masyarakat kelompok PKH di Kelurahan Deli Tua Barat Kecamatan Deli Tua yang sudah dilakukan, maka dapat ditarik beberapa kesimpulan sebagai berikut:

a. Adanya produk baru berupa cake, bolu dan donat berbahan dasar tape.

b. Adanya alat bantu produksi berupa mixer, oven, dan ampia.

c. Kelompok PKH memiliki desain kemasan produk baru.

d. Kelompok PKH memiliki keterampilan dalam membuat produk baru, mendesain kemasan serta 
pengelolaan kelompok Program Keluarga Harapan.

\section{UCAPAN TERIMA KASIH}

Ucapan terima kasih terutama ditujukan kepada :

1. Universitas Negeri Medan, yang telah membiayai Program Pengabdian kepada Masyarakat melalui dana DIPA BOPTN Universitas Negeri Medan Tahun Anggaran 2017

2. Lembaga Pengabdian Masyarakat UNIMED, yang telah menyelenggarakan Program Pengabdian kepada Masyarakat Tahun Anggaran 2017.

3. Pemerintah Kelurahan Deli Tua Barat dan Pemerintahan Kecamatan Deli Tua, yang telah bersedia memfasilitasi kegiatan selama Program Pengabdian kepada Masyarakat dilaksanakan.

4. Kelompok Program Keluarga Harapana, yang telah bersedia menjadi mitra untuk menciptakan kelompok usaha yang mandiri secara ekonomi. 